\title{
DEMONOPOLISASI PT KAI (PERSERO) DAN PT PELINDO (PERSERO) PENGUATAN SISTEM EKONOMI DEMOKRASI ${ }^{*}$
}

\author{
Putu Samawati** \\ Bagian Hukum Perdata, Fakultas Hukum Universitas Sriwijaya, \\ Jalan Raya Palembang Prabumulih KM.35 Inderalaya, Sumatera Selatan 30862
}

\begin{abstract}
Demonopolization of PT KAI (Persero) and PT Pelindo (Persero), intend to make State Owned Enterprise (SOES) as an independent corporation by balancing between profit motives and running a business for public benefit. The opening up of opportunities for private companies to become competitors of SOEs which is a company that has been running a monopoly business, aiming to make SOEs as large corporations that are survive and compete, also remain an agent of development. Strengthening SOEs was done through normative by using documentary research. SOEs is expected to be the main business entity that plays a role in national development, by combining corporate/business and public service principles, which are able to be independent and compete globally but still rely on the concept of economic democracy as a distinctive feature of the Indonesian nation.
\end{abstract}

Keywords: demonopolization, PT KAI (Persero), PT Pelindo (Persero), democratic economic.

\section{Intisari}

Demonopolisasi BUMN Persero yang dilakukan terhadap PT KAI (Persero) dan PT Pelindo (Persero), menghendaki BUMN Persero sebagai korporasi yang mandiri yang mampu menyeimbangkan antara tujuan kegiatan usaha untuk profit motif sekaligus menjalankan usaha untuk kemanfaatan umum. Dibukanya peluang perusahaan swasta menjadi kompetitor BUMN Persero yang selama ini menjalani usaha secara monopoli, bertujuan untuk menjadikan BUMN Persero sebagai korporasi besar yang kuat bertahan dan bersaing, serta tetap menjadi agent of development. Penguatan terhadap BUMN Persero dilakukan melalui penelitian normatif dengan mengguakan documentary research. BUMN Persero diharapkan dapat menjadi badan usaha utama yang berperan dalam pembangunan nasional, dengan memadukan prinsip-prinsip korporat/bisnis dan pelayanan publik, yang mampu mandiri dan bersaing secara global tetapi tetap berpijak pada konsep ekonomi demokrasi sebagai ciri khas bangsa Indonesia.

Kata Kunci: demonopolisasi, PT KAI (Persero), PT Pelindo (Persero), ekonomi demokrasi.

\section{Pokok Muatan}

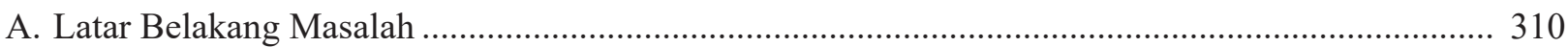

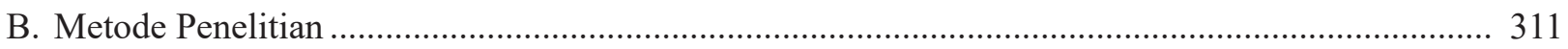

C. Hasil Penelitian dan Pembahasan ......................................................................................... 311

1. Konsep Demonopolisasi BUMN Pada Upaya Pemantapan Demokrasi Ekonomi Berdasarkan Konstitusi Indonesia

2. PT KAI (Persero) dan PT Pelindo (Persero) Bukti Implementasi Peran Negara dalam Mekanisme Pasar.

3. Keunggulan Kebijakan Demonopolisasi PT KAI (Persero) dan PT Pelindo (Persero) bagi Penguatan Ekonomi Indonesia.

D. Kesimpulan ...

Bagian hasil penelitian disertasi Doktor Ilmu Hukum Fakultas Hukum Universitas Gadjah Mada, September 2017-April 2019.

Alamat korespondensi: putusamawati80@gmail.com. 


\section{A. Latar Belakang Masalah}

Demonopolisasi terhadap PT KAI (Persero) dilakukan dengan diterbitkannya Undang-undang Nomor 23 Tahun 2007 tentang Perkeretaapian (selanjutnya ditulis UU No. 23/2007), yang secara tegas menghapus monopoli KAI (Persero) yang dinyatakan dalam Pasal 23, bahwa Penyelenggaraan prasarana perkeretaapian umum berupa kegiatan; pembangunan prasarana perkeretaapian; pengoperasian prasarana perkeretaapian; perawatan prasarana perkeretaapian; dan pengusahaan prasarana perkeretaapian, dilakukan oleh Badan Usaha sebagai penyelenggara, baik secara sendirisendiri maupun melalui kerja sama. Merujuk pengertian badan usaha pada Pasal 1 angka 10 UU No. 23/2007, dinyatakan bahwa Badan Usaha adalah Badan Usaha Milik Negara (BUMN), Badan Usaha Milik Daerah (BUMD), atau badan hukum Indonesia yang khusus didirikan untuk perkeretaapian. Pernyataan ini jelas menyebutkan bahwa sektor swasta dalam bentuk badan hukum boleh masuk dan ikut dalam penyelenggaraan usaha perkeretaapian. Hal ini juga menegaskan bahwa ketentuan Pasal 23 UU No. 23/2007 menghapus monopoli KAI berdasarkan ketentuan Pasal 4 dan 6 Undang-Undang Nomor 13 Tahun 1992 tentang Perkeretaapian, yang menegaskan bahwa badan penyelenggaraan perkeretaapian hanya dilakukan oleh BUMN.

Lebih lanjut penegasan demonopolisasi dinyatakan dalam Pasal 214, bahwa dalam waktu paling lama 3 (tiga) tahun sejak Undang-Undang ini berlaku, penyelenggaraan prasarana perkeretaapian dan sarana perkeretaapian yang dilaksanakan oleh Badan Usaha sebagaimana dimaksud pada ayat (1) serta penyelenggaraan prasarana perkeretaapian milik pemerintah wajib disesuaikan dengan ketentuan sebagaimana diatur dalam UndangUndang ini. Pernyataan ini menginstruksikan kepada BUMN KAI paling lambat tanggal 25 April 2010 PT KAI (Persero) sudah harus melepaskan kedudukan monopolinya. Hal ini mengacu pada ketentuan Pasal
23 yang memberikan peluang kepada swasta untuk menjadi kompetitor KAI, selain itu ketentuan Pasal 13 dan 17 yang memisahkan peran negara sebagai pembina dan peran penyelenggaraan perkeretaapian diserahkan kepada Badan Usaha. Penegasan lanjutan dijabarkan dalam Penjelasan Umum alenia keempat, kelima, dan keenam UU No. 23/2007.

Selain PT KAI (Persero) yang didemonopolisasi, PT Pelindo (Persero) juga didemonopolisasi melalui melalui Undang-Undang Nomor 17 Tahun 2008 tentang Pelayaran (selanjutnya ditulis UU No. 17/2008), yang secara tegas dinyatakan pada Penjelasan Umum bagian b, bahwa pengaturan untuk bidang kepelabuhanan memuat ketentuan mengenai penghapusan monopoli dalam penyelenggaraan pelabuhan, pemisahan antara fungsi regulator dan operator serta memberikan peran serta pemerintah daerah dan swasta secara proporsional di dalam penyelenggaraan kepelabuhanan. Selain itu juga diatur mengenai badan usaha penyelenggara pelabuhan yang dapat dilakukan oleh Badan Usaha Milik Negara (BUMN), Badan Usaha Milik Swasta (BUMS), atau perorangan, yang secara rinci terdapat dalam Pasal 1 angka 28, Pasal 1 angka 60, Pasal 91 ayat (1), Pasal 91 ayat (5), dan Pasal 92 UU No. 17/2008.

Kebijakan demonopolisasi yang diberlakukan pada PT KAI (Persero) dan PT Pelindo (Persero) didasarkan pada keinginan pemerintah untuk mempersiapkan badan usaha tersebut dalam menghadapi tuntutan globalisasi perdagangan bebas. Harapan dengan memperkuat kelembagaan BUMN agar dapat menjalankan kegiatan usaha secara profesional yang menerapkan prinsip korporatisasi, tetapi tetap berpijak pada tujuan pendirian untuk melindungi aset negara dan memberikan kemanfaatan bagi masyarakat Indonesia. Keberadaan Badan Usaha Milik Negara yang didemonopolisasi pemerintah memang ditujukan untuk merevitalisasi BUMN agar mampu memiliki daya saing dengan badan usaha milik swasta. Demonopolisasi ${ }^{1}$ adalah kondisi BUMN

Niels Petersen, “Antitrust Law and The Promotion of Democracy and Economic Growth”, Journal of Competition Law \& Economic, Vol. 9, No. 3, 14 May 2013, hlm. 603. 
yang semula mendapatkan hak monopoli dalam menjalankan usaha pada sektor-sektor strategis dan vital, selanjutnya hak tersebut dicabut melalui peraturan perundang-undangan, sehingga memberi peluang swasta untuk mendirikan jenis usaha yang sama. Menciptakan pesaing baru dalam menjalankan usaha yang selama ini dimonopoli adalah langkah yang diharapkan agar BUMN mampu memperbaiki kinerjanya. Konsep kebijakan demonopolisasi BUMN belum banyak dikenal oleh pemangku kebijakan di Indonesia. Hal yang sering digaungkan adalah privatisasi BUMN. Demonopolisasi hanya menciptakan kompetitor bagi BUMN untuk bersaing, tetapi kepemilikan badan usaha tetap berada pada pemerintah, berbeda dengan privatisasi yang mengurangi atau bahkan menghilangkan kepemilikan pemerintah terhadap BUMN. Atas dasar hal tersebut perlu diberikan pemaknaan konsep demonopolisasi BUMN sebagai strategi penguatan demokrasi ekonomi berdasarkan Konstitusi Republik Indonesia yang mengedepankan kemakmuran rakyat melalui pengelolaan ekonomi berdasarkan asas kekeluargaan.

\section{B. Metode Penelitian}

Jenis penelitian yang digunakan adalah penelitian hukum normatif. ${ }^{2}$ Peneliti mencoba menjawab permasalahan dari segi asas-asas dan norma hukum, yang sifatnya memberikan gambaran tentang rasionalisasi kebijakan demonopolisasi dan fungsi BUMN sebagai agent of development dengan mengaitkan kebijakan tersebut dalam hukum yang berlaku kepada tatanan kemasyarakatan. ${ }^{3}$ Pendekatan perundangundangan (statute approach) menjadi kunci analisis di samping pendekatan sejarah hukum (legal historical approach), dan pendekatan filosofis (legal philosophy approach). Data yang digunakan adalah data sekunder, yang diperoleh melalui penelitian dokumentari (documentary research). ${ }^{4}$ Setelah data penelitian terkumpul, langkah selanjutnya adalah melakukan pengolahan data, yang diawali dengan mengklasifikasi fakta-fakta, mengklasifikasi tentang masalah hukum yang diteliti, sampai akhirnya mengadakan analisis hukum. ${ }^{5}$ Secara umum, analisis dilakukan dengan metode doktrinal melalui optik preskriptif. ${ }^{6}$ Hasil analisis akan muncul suatu kesimpulan sebagai konsep baru yang menjawab permasalahan secara induktif yang akan memberikan pemahaman konsep demonopolisasi sebagai upaya menguatkan peran BUMN dalam pembangunan nasional yang berkelanjutan melalui pemantapan implementasi konsep demokrasi ekonomi sesuai dengan Konstitusi Indonesia. ${ }^{7}$

\section{Hasil Penelitian dan Pembahasan}

Keberadaan jasa penyelenggara perkeretaapian dan operator pelabuhan dalam pergerakan perekonomian memang memiliki peran yang sangat signifikan. Jalur penghubung antar daerah dan pulau, praktiknya membutuhkan infrastruktur dan sarana penunjang bagi terselenggaranya transportasi umum yang dapat membantu perpindahan orang dan barang. Keterjangkauan masyarakat akan pemenuhan kebutuhan hidup juga dipengaruhi oleh kelancaran mobilitas barang dan jasa dari satu wilayah ke wilayah lainnya. Demografi penduduk dan geografi wilayah Indonesia juga memengaruhi akan kebutuhan sarana transportasi yang berbedabeda di tiap wilayah. Hal utama yang menjadi poin pentingnya adalah keterjangkauan masyarakat akan pemenuhan fasilitas transportasi yang aman dan nyaman untuk mobilitas barang dan jasa sebagai bagian dari kebutuhan hidup mereka. Upaya untuk memenuhi ketersediaan sarana transportasi yang terjangkau ini memang membutuhkan peran

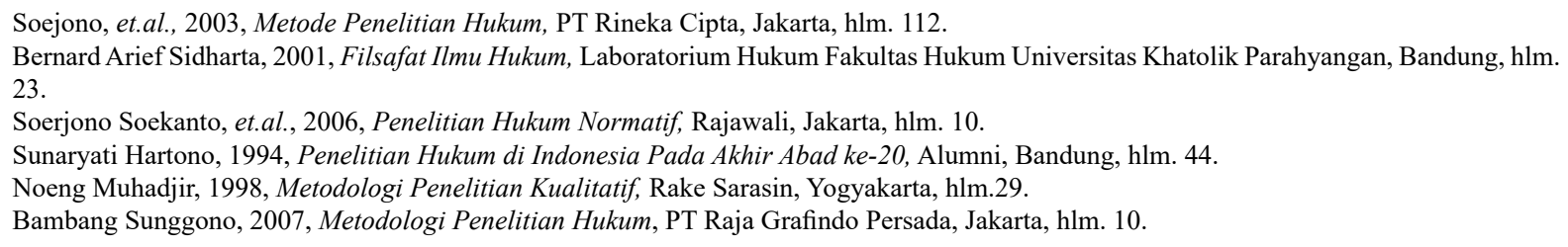


pemerintah, karena pembangunan infrastruktur untuk membuka akses membutuhkan biaya yang besar, biaya yang menurut perhitungan pengusaha tidak bernilai ekonomis. Hal ini dinyatakan oleh Jules Dupuit yang meyakini bahwa jaringan transportasi harus diintervensi oleh pemerintah, karena apabila sepenuhnya dilepaskan pada swasta, maka akan terjadi penyalahgunaan kewenangan. ${ }^{8}$

\section{Konsep Demonopolisasi BUMN Pada Upaya Pemantapan Demokrasi Ekonomi Berdasarkan Konstitusi Indonesia.}

Istilah demonopolisasi merupakan bentuk perubahan dari monopoli, dimana demonopolisasi merupakan usaha penghapusan monopoli ${ }^{9}$, dengan kata lain suatu keadaan dimana suatu badan usaha diberikan hak untuk melakukan monopoli dalam kegiatan usaha tertentu, kemudian hak tersebut dicabut melalui peraturan perundang-undangan yang berlaku. ${ }^{10}$ Demonopolisasi memiliki pengertian yang berbeda dengan privatisasi. Privatisasi merupakan proses distribusi peralihan kepemilikan yang dahulunya dikuasai dan diselenggarakan oleh negara kemudian dialihkan kepada swasta, peralihan tidak hanya berupa aset (saham) BUMN saja tetapi juga meliputi kontrak pelayanan yang dahulunya dilakukan oleh negara kepada swasta ${ }^{11}$. Privatisasi secara sederhana diistilahkan sebagai swastanisasi, dengan kata lain status BUMN yang dimiliki negara secara penuh menjadi milik swasta sebagian atau seluruhnya, artinya ada pengalihan saham milik BUMN kepada swasta lebih dari 51\%.

Beberapa literatur ada yang menyamakan antara demonopolisasi dan privatisasi, seperti yang dilakukan oleh Dewatripont dan Roland dalam artikelnya pada Economic Journal University of
Parto Year 1992 yang berjudul "The Virtues of Gradualism and Legitimacy in The Transition to Market Economiy”. Pernyataan tersebut dibantah oleh Artur Rodriques dan Paulo J Pereira ${ }^{12}$ yang berasal dari universitas yang sama, bahwa demonopolisasi sesungguhnya bersifat lebih umum dan lebih luas lagi, dia merupakan kondisi dimana suatu kegiatan usaha yang semula dimonopoli oleh perusahaan negara selanjutnya hak monopoli tersebut dilepaskan, pelepasan hak monopoli tersebut dapat dilakukan dengan melepaskan saham perusahaan atau dengan mendirikan perusahaan pesaing. Pernyataan serupa juga dinyatakan oleh Liuben Berov, bahwa privatisasi adalah salah satu bentuk/jenis dari demonopolisasi perusahaan negara. ${ }^{13}$ Penulis sepakat dengan pernyataan tersebut, bahwa demonopolisasi bermakna lebih luas daripada privatisasi. Sebagai indikator penegas untuk memberikan batasan pemaknaan demonopolisasi dengan privatisasi, kita dapat menganalisisnya melalui pengertian BUMN dalam Undang-Undang Nomor 19 Tahun 2003 tentang BUMN.

Apabila merujuk kembali pengertian dari BUMN, tersirat pembatasan suatu badan usaha dapat dinyatakan sebagai milik negara apabila modal perusahaan seluruhnya atau sebagian besar dimiliki oleh negara. Pemaknaan kata "sebagian besar" diartikan minimal saham dikuasai sebanyak $51 \%$, artinya apabila modal badan usaha kurang dari 51\%, maka dia tidak dapat dikatakan sebagai badan usaha milik negara. Pembatasan modal 51\% inilah sebagai indikator untuk menyatakan suatu BUMN diprivatisasi, jika total kepemilikan saham negara kurang dari 51\%, maka dapat dikatakan bahwa BUMN tersebut telah diprivatisasi. Berbeda

\footnotetext{
Jules Dupuit, 2016, Monopoli Alamiah Badan Usaha Milik Negara, Herya Media, Depok, hlm. 147.

Kamus Besar Bahasa Indonesia online, http://kbbi.web.id/demonopolisasi.html, diakses 25 Mei 2016.

Jay G. Martin, “An Overview of The Privatization of The Latin American Oil and Gas Sector", Natural Resources \& Environment Journal, Vol. 14, No. 2, Tahun 1999, hlm. 103 - 110.

11 Ewa Baginska, "Privatization Proses in Poland: Legal Aspect of The Privatization Process in Poland", Makalah, Nicolaus Copernicus University, Poland, 1995, hlm. 1

12 Artur Rodriques, et.al., "Investment Decisions in Granted Monopolies Under The Threat of a Random Demonopolization", Economic Jornal Faculty of Economic University of Parto, Portugal, Januari 2011, hlm. 2.

13 Liuben Berov, "Demonopolization and International Competition in Bulgaria 1990-1991", Russian and Eastern European Finance and Trade Journal, Vol. 29, No.1, Tahun 1993, hlm. 89.
} 
pemaknaannya apabila negara hanya melepaskan saham kepada swasta kurang dari 51\%, maka mekanisme ini disebut sebagai upaya negara untuk menerapkan budaya korporat dalam BUMN (korporatisasi BUMN). Jangkauan demonopolisasi adalah kepemilikan BUMN yang masih berada di tangan pemerintah, dengan kata lain kepemilikan saham negara pada BUMN jumlahnya berkisar antara 51\% - 100\%, sehingga kebijakan pengelolaan BUMN didasarkan pada mekanisme RUPS yang merupakan organ tertinggi dalam sebuah perseroan. $^{14}$

Ada kekhawatiran ketika kebijakan demonopolisasi diberlakukan, yaitu persoalan perlindungan aset kekayaan negara dan perlindungan terhadap pemenuhan hajat hidup orang banyak yang merupakan amanah dari Pasal 33 UUD 1945 sebagai Konstitusi Republik Indonesia. Anggoro ${ }^{15}$ berpendapat, setidaknya ada dua upaya terstruktur yang diasumsikan melemahkan peran negara dalam perekonomian dengan diberlakukannya kebijakan demonopolisasi terhadap BUMN, yaitu:

1. Investasi asing diberikan kesempatan yang luas untuk berusaha di berbagai sektor perekonomian Indonesia termasuk pada sektor industri strategis dan vital.

2. Memberikan kesempatan kepada badan usaha swasta untuk berkompetisi dengan BUMN sekalipun untuk barang yang memiliki karakter publik.

Pengaruh ekonomi neoliberal ${ }^{16}$ dianggap sebagai faktor yang mendorong pemerintah memberlakukan kebijakan demonopolisasi BUMN. Di sisi lain ada komitmen pemerintah terhadap pemenuhan tuntutan globalisasi/pasar bebas, sehingga mau tidak mau harus mengikuti perkembangan dunia usaha internasional agar tidak tertinggal dalam pergaulanan internasional. Atas dasar mengikuti perkembangan perekonomian internasional inilah, maka penyelenggaraan perkeretaapian dan jasa kepelabuhan didemonopolisasi. $^{17}$

Demonopolisasi merupakan upaya untuk mendorong swasta agar dapat menjadi pesaing bisnis bagi $\mathrm{BUMN}^{18}$, sasarannya untuk meningkatkan kinerja perusahaan yang bersaing secara sehat dan peningkatan pelayanan kepada konsumen/ masyarakat, sehingga tercipta pasar persaingan sempurna. ${ }^{19}$ Hal yang menjadi poin penting adalah bahwa pada dasarnya negara memiliki 5 fungsi hak menguasai, yaitu sebagai penentu kebijakan(beleid), melakukan tindakan pengurusan (bestuursdaad), melakukan pengaturan (regelendaad), melakukan pengelolaan (beheersdaad), dan pengawasan (toezichthoudensdaad). ${ }^{20}$ Kelima fungsi ini dapat dilaksanakan dalam bentuk strategi perbaikan eksternal dan internal perusahaan dengan menguatkan konsep demonopoliasasi dan korporatisasi yang merupakan upaya meningkatkan peran BUMN agar mampu mandiri, bersaing, dan turut andil dalam perekonomian nasional.

Mahkamah Konstitusi menempatkan pengelolaan secara langsung oleh Negara atas

14 Lihat Pasal 1 ayat (3), Pasal 82 ayat (1), dan Pasal 97 ayat (1) Undang-Undang Nomor 40 Tahun 2007 tentang Perseroan Terbatas, Lembaran Negara Republik Indonesia Tahun 2007 Nomor 106, Tambahan Lembaran Negara Republik Indonesia Nomor 4756.

15 Teddy Anggoro, 2016, Monopoli Alamiah Badan Usaha Milik Negara, Herya Media, Depok, hlm.126.

16 Kwik Kian Gie, 1998, Praktek Bisnis dan Orientasi Ekonomi Indonesia, PT Gramedia Pustaka Utama \& IBBI, Jakarta, hlm. 36.

17 Penjelasan Umum alenia keempat Undang-Undang Nomor 23 Tahun 2007 juga memuat pernyataan bahwa, dengan adanya perkembangan teknologi perkeretaapian dan perubahan lingkungan strategis yang semakin kompetitif dan tidak terpisahkan dari sistem perekonomian internasional yang menitikberatkan pada asas keadilan, keterbukaan, dan tidak diskriminatif, dipandang perlu melibatkan peran pemerintah daerah dan swasta guna mendorong kemajuan penyelenggaraan perkeretaapian nasional. Bagian menimbang huruf d Undang-Undang Nomor 17 Tahun 2008 tentang Pelayaran, menyatakan bahwa perkembangan lingkungan strategis nasional dan internasional menuntut penyelenggaraan pelayanan yang sesuai dengan perkembangan ilmu pengetahuian dan teknologi, peran serta swasta dan persaingan usaha, otonomi daerah, dan akuntabilitas penyelenggara negara, dengan tetap mengutamakan keselamatan dan keamanan pelayaran demi kepentingan nasional.

18 Niels Petersen, "Antitrust Law and The Promotion of Democracy and Economic Growth", Journal of Competition Law \& Economic, Vol. 9, No. 3, Tahun 2013, hlm. 603.

19 Joseph E. Stiglizt, 2007, Making Globalization Work: Menyiasati Globalisasi Menuju Dunia yang Lebih Adil, Diterjemahkan oleh Edrijani Azwaldi, Mizan, Bandung, hlm. 135.

20 Putusan Mahkamah Konstitusi Nomor 002/PUU-I/2003 tentang Pengujian Undang-Undang Nomor 22 Tahun 2001 tentang Minyak dan Gas Bumi, 21 Desember 2004. 
cabang-cabang produksi penting dan bumi, air, serta kekayaan alam lainnya sebagai peringkat pertama, diikuti oleh fungsi kebijakan dan pengurusan pada peringkat kedua, dan fungsi pengaturan dan pengawasan pada peringkat ketiga. ${ }^{21}$ Pertimbangan Mahkamah Konstitusi didasarkan pada pernyataan bahwa, sepanjang negara memiliki kemampuan baik modal, teknologi, dan manajemen dalam pengelolaan sumber daya alam, maka negara harus memilih untuk melakukan pengelolaan secara langsung atas sumber daya alam tersebut. Dengan pengelolaan secara langsung, dipastikan seluruh hasil dan keuntungan yang diperoleh akan masuk menjadi keuntungan negara yang secara tidak langsung akan membawa manfaat lebih besar bagi rakyat. Pengelolaan langsung yang dimaksud di sini dalam bentuk pengelolaan langsung oleh negara melalui BUMN. Pada sisi lain, jika negara menyerahkan pengelolaan sumber daya alam untuk dikelola oleh perusahaan swasta atau badan hukum lain di luar negara, keuntungan bagi negara akan terbagi, sehingga manfaat bagi rakyat juga akan berkurang. ${ }^{22}$

Dasar pembenar kebijakan demonopolisasi BUMN dapat dikaitkan dengan konsep dikuasai negara menurut Moh. Hatta ${ }^{23}$, yang menyatakan bahwa, "dikuasai negara" tidak berarti bahwa negara sendiri menjadi pengusaha, tetapi cukup apabila kekuasaan negara terdapat pada pembuatan peraturan guna melancarkan jalannya ekonomi. Mengenai persoalan dikuasai negara, Emil Salim ${ }^{24}$ (1985) berpendapat, bahwa istilah dikuasai oleh negara mempunyai pengertian sebagai; pemilik, pengatur, perencana, pelaksana, dan pengawas. Rumusan kelima pengertian ini dengan bobot yang berlainan dapat menempatkan negara dalam kedudukannya untuk menguasai dapat dengan memiliki dan mengelola langsung cabang produksi penting dan sumber daya alam. Hal lain negara juga dapat tanpa memiliki dan mengelola langsung cabang produksi penting dan sumber daya alam, namun negara sebagai pemegang kedaulatan, memanfaatkan jalur pengaturan, perencanaan, dan pengawasan terhadap bidang tersebut. Pandangan ini menempatkan pemerintah untuk berperan sesuai dengan situasi dan kondisi perkembangan zaman yang selalu menghendaki penyesuaian mengikuti arah kebijakan global yang menginginkan pasar bebas tanpa ada batasan dan hambatan berusaha. Hal mendasar yang harus menjadi perhatian dari pemerintah adalah persoalan jaminan perlindungan pemenuhan kebutuhan hajat hidup masyarakat banyak dan perlindungan akan keberadaan kekayaan alam Indonesia yang berkelanjutan.

Pemerintah sebagai wakil negara memiliki kewajiban untuk melaksanakan tugas negara, di antaranya adalah menyelenggarakan pelayanan umum (public service). BUMN merupakan alat pemerintah yang digunakan untuk menunjang tugas negara dalam keberhasilan pembangunan, karena peranan BUMN sebagai wahana pembangunan yang berbeda daripada sebagai perusahaan umumnya. BUMN sebagai wahana pembangunan dituntut untuk harus mampu menjalankan usaha vital dan pembangunan proyek-proyek tertentu yang tidak terdapat dalam rencana pembangunan yang ditetapkan semula. ${ }^{25}$ Tuntutan BUMN untuk mampu mandiri dan bersaing dengan swasta dilakukan dalam upaya membuka pasar persaingan secara global. Atas dasar hal tersebutlah diperlukan strategi penguatan bagi peran BUMN agar mampu mendukung perekonomian nasional yang berkelanjutan. Penataan BUMN secara intern dan ekstern kelembagaan merupakan poin penting sebelum pemerintah memberlakukan kebijakan demonopolisasi.

\footnotetext{
Putusan Mahkamah Konstitusi No. 36/PUU-X/2012 tentang Pengujian Undang-Undang Nomor 22 Tahun 2001 tentang Minyak dan Gas Bumi, 13 November 2012.

23 Mohammad Hatta, 1970, “Sesudah 25 Tahun”, dalam Revrisond Baswir, 2010, Manifesto Ekonomi Kerakyatan, Pustaka Pelajar, Yogyakarta, hlm. 31-32.

24 Emil Salim, 2010, Pokok-pokok Pikiran: membangun Koperasi dan Sistem Ekonomi Pancasila, dalam Sri Edi Swasono (ed.), 2010, Membangun Sistem Ekonomi Nasional-Sistem Ekonomi dan Demokrasi Ekonomi, UI Press, Jakarta, hlm. 61.

25 Rahayu Hartini, 2017, BUMN Persero: Konsep Keuangan Negara dan Hukum Kepailitan di Indonesia, Setara Press, Malang, hlm. 40.
} 
Konsep demonopolisasi menginginkan BUMN dapat dijalankan dengan mekanisme korporat (dikorporatisasi) melalui pembenahan dan penguatan kelembagaan, manajemen, dan sumber daya manusianya. Harapannya BUMN dapat berkompetisi dengan swasta tetapi tetap memberikan keuntungan bagi negara dan masyarakat Indonesia. Prinsip dasarpengelolaanBUMNyang menghendaki diterapkannya asas ekonomi demokrasi atau ekonomi kerakyatan memberi keistimewaan BUMN sebagai badan usaha yang bekerja secara koperatif (berjiwa koperasi). Pada badan usaha yang berjiwa koperatif mekanisme berupa keterlibatan partisipasi karyawan dalam kepemilikan saham atau pun pembagian laba/pendapatan perusahaan, serta menerapkan corporate social responsibility, mengindikasikan bahwa BUMN telah memenuhi asas kekeluargaan dalam menjalankan usahanya seperti yang diinginkan oleh konsep demokrasi ekonomi atau ekonomi kerakyatan.

Realisasi konsep demonopolisasi BUMN berdasarkan prinsip demokrasi ekonomi ini adalah menguatkan tujuan dasar pendirian BUMN dengan pembenahan interen maupun eksteren kelembagaan BUMN agar perannya sebagai agent of development dapat terealisasi. Hal utama lainnya adalah pemerintah harus memberikan kesempatan pertama kepada badan usaha swasta milik pribumi untuk menjadi kompetitor BUMN. Hal ini dilakukan sebagai upaya untuk mengembalikan kemanfaatan pengolahan sumber daya manusia dan sumber daya alam Indonesia kepada bangsa Indonesia sendiri. Opsi terakhir barulah memberikan peluang kepada investor asing untuk menjadi kompetitor BUMN, dengan penetapan aturan pelaksanaan kegiatan usaha berdasarkan kebijakan negara yang dikuatkan dalam aturan perundang-undangan. Fungsi negara diposisikan sebagai penentu kebijakan, melakukan pengaturan, dan pengawasan bagi badan usaha swasta yang menjadi kompetitor BUMN. ${ }^{26}$

\section{PT KAI (Persero) dan PT Pelindo (Persero) Bukti Implementasi Peran Negara dalam Mekanisme Pasar.}

Penyelenggaraan sarana prasarana perkeretaapian dan kepelabuhan merupakan bentuk kegiatan usaha yang menyangkut hajat hidup rakyat banyak dan menurut Konstitusi Republik Indonesia harus melibatkan peran negara di dalamnya. Frase menguasai hajat hidup orang banyak dalam artian pemberian pelayanan publik (pubic utilities) merupakanfaktorpenentubahwa suatu usahamenjadi perhatian dan prioritas pemerintah. Mohammad Hatta telah menegaskan dalam pandangannya, bahwa public utilities diusahakan oleh pemerintah/ negara guna menjalankan perekonomian nasional yang berbasis kemandirian dan efisiensi yang tujuan akhirnya memenuhi kebutuhan konsumen, dalam hal ini masyarakat secara menyeluruh. ${ }^{27}$ Pendapat lain mengenai pemaknaan bidang usaha/cabangcabang produksi yang menyangkut hajat hidup orang banyak dikemukakan oleh Ace Partadiredja, yang menyatakan bahwa semua cabang produksi barang dan jasa yang hasilnya dipakai oleh semua orang, atau hampir semua orang. Hal yang perlu menjadi catatan bahwa indikator menguasai hajat hidup orang banyak juga mengalami perubahan yang dipengaruhi oleh kondisi lingkungan masyarakat dan waktu kejadian. Hal ini dimaksudkan dengan suatu kondisi bisa saja saat ini sesuatu itu dianggap menguasai hajat hidup orang banyak, kemudian perkembangan peradaban selanjutnya ia tidak lagi dianggap sebagai sesuatu yang menguasai hajat hidup orang banyak. ${ }^{28}$

Penegasan lebih lanjut mengenai pemaknaan cabang-cabang produksi yang menguasai hajat hidup orang banyak dikemukakan oleh Prabowo ${ }^{29}$, yang menyatakan orang banyak mempunyai arti

\footnotetext{
26 Hal ini sudah diatur dalam Pasal 80 Undang-Undang Nomor 17 Tahun 2008 tentang Pelayaran dan Pasal 13 Undang-Undang Nomor 23 Tahun 2007 tentang Perkeretaapian, yang menempatkan pemerintah sebagai penyelenggara pengaturan, pembinaan, pengendalian, dan pengawasan. Mohammad Hatta, "Pelaksanaan Undang-undang Dasar 1945 Pasal 33", Majalah Gema Angkatan 45, Tahun 1977, hlm. 5.

Mubyarto, et.al., 1989, Pelaku dan Politik Ekonomi Indonesia, UGM Press, Yogyakarta, hlm. 74.

Dibyo Prabowo, Penjabaran Pasal 33 ayat (2) UUD 1945 dalam Kebijaksanaan, dalam Mubyarto dan Revrison Baswir, Ibid., hlm. 81.
} 
absolut yaitu banyak yang membutuhkan. Sampai kapanpun tetap disebut sebagai hajat hidup orang banyak, berlaku untuk seterusnya dan mempunyai batas waktu. Lebih lanjut dalam Undang-Undang Nomor 25 Tahun 2009 tentang Pelayanan Publik, terdapat dalam penjelasan Pasal 5 ayat (4) yang menegaskan bahwa jasa publik yang dihasilkan oleh BUMN atau BUMD yang mendapat pelimpahan tugas untuk menyelenggarakan pelayanan publik, PT KAI (Persero) dan PT Pelindo (Persero) merupakan BUMN yang termasuk kedalam kategori perusahaan yang mendapat pelimpahan tugas menyelenggarakan pelayanan publik dalam hal penyelenggaraan perkeretaapian dan kepelabuhan.

Peran negara dalam bentuk keterlibatan pada sektor pengelolaan penyelenggaraan perkeretaapian dan kepelabuhan, di satu sisi berfungsi untuk memenuhi keterjangkauan masyarakat akan layanan transportasi orang dan barang. Di sisi lain melahirkan ketidakefisienan dalam pengelolaan kedua bidang usaha tersebut. Sebagai contoh pada sektor penyelenggaraan pelabuhan, biaya pelabuhan (terminal handling charge) untuk kontainer standar 45 di Indonesia pada Pelabuhan Tanjung Priok adalah 255 dolar Amerika per kontainer, lebih mahal dibandingkan di Singapura sebesar 243 dolar Amerika, Malaysia dengan harga 173 dolar Amerika, atau Thailand dengan harga 155 dolar Amerika, atau bahkan Filipina yang hanya 138 dolar Amerika. ${ }^{30}$ Persoalan kurangnya efisiensi dalam menjalankan kegiatan usaha juga dialami oleh perkeretaapian di Indonesia, rel kereta api di sepanjang pulau Jawa tidak pernah bertambah dari jalur yang diwarisi oleh kolonial Hindia Belanda, bahkan di pulau Sumatera panjang rel kereta apinya justru mengalami pengurangan dibandingkan dengan zaman Hindia Belanda, apalagi bicara pengembangan usaha perkeretaapian di luar pulau Jawa dan Sumatera, hingga saat ini hal tersebut belum mampu direalisasikan. ${ }^{31}$

Persoalan mendasar yang dihadapi oleh PT KAI (Persero) sebagai BUMN perkeretaapian dan PT Pelindo (Persero) sebagai BUMN operator pelabuhan adalah praktik kegiatan usahanya yang masih bersifat monopolistik. Memang Undang-Undang Perkeretaapian dan Undang-Undang Pelayaran telah memberikan ketentuan demonopolisasi terhadap kegiatan usaha penyelenggaraan perkeretaapian dan operator pelabuhan. Monopolistik yang terjadi pada PT KAI (Persero) dan PT Pelindo (Persero) didasarkan pada kondisi kedudukan monopoli alamiah dari kedua jenis BUMN tersebut. Hal ini terjadi karena timbulnya hambatan alamiah berupa biaya investasi yang besar. Kegiatan usaha yang dilakukan oleh PT KAI (Persero) dan PT Pelindo (Persero) merupakan jenis industri yang menarik bagi swasta, tetapi tidak ekonomis mengingat durasi return of investment terlalu panjang, argumentasi fixed cost tinggi tetapi biaya variabel rendah atau bahkan tidak ada sama sekali. ${ }^{32}$

PT KAI (Persero) dan PT Pelindo (Persero) sebagai BUMN yang menjalankan kegiatan usaha perkeretaapian dan operator pelabuhan memang dihadapkan dengan kondisi menjalankan kegiatan usaha yang tidak lagi dimonopoli. Kebijakan demonopolisasi kedua jenis BUMN tersebut dikehendaki oleh pemerintah atas dasar partisipasi penyelenggaraan pasar bebas. ide pelaksanaan kebijakan pasar bebas itu didasarkan pada konsep opportunity cost dalam menghasilkan barang lain. Dasar pemikirannya adalah satu masyarakat atau negara memiliki sumber daya yang berbeda jumlah dan jenisnya dengan negara lain, oleh karena itu, setiap masyarakat atau negara akan memperoleh keuntungan dengan melakukan spesialisasi yang didasarkan pada keunggulan relatif yang kemudian dilanjutkan dengan perdagangan secara bebas.

\footnotetext{
3 Badan Perencanaan dan Pembangunan Nasional, 2015, "Biaya pelabuhan”, Tim Investasi, Direktorat Perencanaan Makro, Bappenas, https:// www.bappenas.go.id/files/, diakses 7 Februari 2017, hlm. 91.

Jimly Asshiddiqie, 2010, Konstitusi Ekonomi, Kompas, Jakarta, hlm. 275

32 Teddy Anggoro, Op. cit., hlm. 434 - 435, lihat juga Rian Juanda Djamani, "Efisiensi Pelabuhan untuk Menekan Biaya Logistik", Asosiasi Logistik Indonesia, http://www.ali.web.id/web2/publication_detail.php?id=528, diakses 2 Februari 2019.
} 
Spesialisasi cenderung meningkatkan efisiensi. Dengan demikian, setiap negara akan memperoleh keuntungan yang berupa kenaikan pendapatan, konsumen memperoleh harga yang lebih murah, alternatifbarang yang lebih banyak, dan perdagangan bebas akan menjadi motor pertumbuhan ekonomi. ${ }^{33}$

Meskipun kebijakan demonopolisasi terhadap PT KAI (Persero) dan PT Pelindo (Persero) salah satunya dilatarbelakangi oleh desakan globalisasi sebagai pelaksanaan perdagangan bebas, tetapi tujuan utama dari pemerintah memberlakukan peraturan mengenai demonopolisasi BUMN adalah memberikan kesempatan kepada swasta untuk ikut berperan dalam pembangunan perekonomian nasional. Kesempatan berusaha kepada swasta untuk mendirikan dan menjalankan badan usaha yang melakukan kegiatan dalam penyelenggaraan perkeretaapian atau operator pelabuhan adalah langkah untuk menciptakan kompetitor bagi PT KAI (Persero) dan PT Pelindo (Persero). Upaya ini dimaksudkan untuk memenuhi kebutuhan masyarakat pengguna atau pemanfaat sektor jasa kereta api dan jasa kepelabuhan, dengan memberikan pilihan penyedia jasa yang berkompetisi dalam hal tarif dan mutu pelayanan. Harapan besar yang disandarkan pada PT KAI (Persero) dan PT Pelindo (Persero) adalah kemampuan untuk meningkatkan efisiensi dan efektifitas kinerja perusahaan, sehingga perusahaan mampu mencapai nilai sehat dalam prestasi kerjanya.

Kinerja BUMN diartikan sebagai prestasi yang dicapai BUMN dalam suatu periode tertentu yang mencerminkan tingkat kesehatan BUMN. ${ }^{34}$ Menurut Keputusan Menteri Keuangan RI Nomor 740/KMK.00/1989 tanggal 24 Juni 1989 tentang Peningkatan Efisiensi dan Produktivitas BUMN dan Keputusan Menteri Keuangan RI No. 826/ KMK.123/1992 tanggal 24 Juli 1992 tentang
Perubahan Keputusan Menteri Keuangan RI Nomor 740/KMK.001/1989, tingkat kesehatan perusahaan dapat digolongkan menjadi empat tingkatan yakni; sehat sekali, sehat, kurang sehat, dan tidak sehat. Indikator penentuan dalam pengukur kinerja BUMN adalah seberapa besar BUMN memperoleh keuntungan sebagai bagian dari tujuan didirikannya BUMN tersebut. BUMN harus memacu semaksimal mungkin segala potensi yang dimiliki untuk mendatangkan keuntungan. Ketika Pemerintah harus mengurangi bantuan modal dan perusahaan harus menghadapi tingkat persaingan yang semakin kompetitif, strategi yang dapat dilakukan adalah memacu produktivitas, sasaran utamanya adalah menjadikan BUMN terkategori sebagai badan usaha yang sehat. Mar'ie Muhammad mengatakan bahwa walaupun terdapat keterbatasan untuk mengukur prestasi BUMN, tetapi beberapa indikator seperti, biaya produksi per unit; rasio laba terhadap pendapatan; rasio sales/output terhadap jumlah karyawan; value added dalam 1 tahun; kontribusi BUMN terhadap negara berupa dividen dan pajak; dan keberhasilan BUMN melaksanakan program investasi dan penugasan yang diberikan pemerintah, cukup efektif sebagai pengukur kinerja dari BUMN tentunya dengan batasan periode tertentu. ${ }^{35}$

Mengenai pengukuran kinerja BUMN telah diatur melalui Keputusan Menteri Keuangan Republik Indonesia Nomor 826/KMK.013/1992, yang dimaksud dengan penilaian kinerja BUMN adalah penilaian terhadap efisiensi dan produktivitas perusahaan yang dilakukan secara berkala atas dasar laporan manajemen dan laporan keuangan. Kriteria kinerja BUMN diperoleh dengan menghitung nilai bobot kondisi keuangan berdasarkan indikator rasio Rentabilitas, Likuiditas, dan Solvabilitas, masing-masing dengan bobot $75 \%, 12,5 \%$ dan $12,5 \%{ }^{36}$ Ketika suatu BUMN dinyatakan sehat

\footnotetext{
33 Mordechai E. Kreinin, 1990, International Economics; A Policy Approach, Harcout Brace Javanovich Inc., New York, hlm. 16.

34 Bab 1 Pasal 1 Butir 11 Keputusan Menteri Keuangan RI Nomor 740/KMK.00/1989 tanggal 28 Juni 1989 tentang Peningkatan Efisiensi dan Produktifitas BUMN.

35 Andini Tri Diana, "Analisis Tingkat Kesehatan Perusahaan dalam Menilai Kinerja Keuangan Perusahaan BUMN", Jurnal Integra, Vol. 6, No.1, Januari 2016, Diterbitkan Oleh Sekolah Tinggi Ilmu Ekonomi Indonesia Pontianak, hlm. 17.

36 Agus R. Sartono, 1999, Manajemen Keuangan Teori dan Aplikasi, BPFE UGM, Yogyakarta, hlm. 12
} 
atau sehat sekali, maka BUMN tersebut akan mampu menghadapi tantangan globalisasi yang menghendaki perdagangan bebas, dengan kata lain, BUMN tersebut akan mampu menghadapi kompetitor dari badan usaha swasta. Berdasarkan uraian di atas diketahui bahwa PT KAI (Persero) dan PT Pelindo (Persero) adalah perusahaan dengan kondisi keuangan perusahaan dengan keuntungan usaha perseroan tahun 2017 mengalami peningkatan dari keuntungan penghasilan di tahun 2016. Kondisi keuntungan usaha kedua jenis BUMN ini terdapat dalam tabel berikut:

Tabel 1.

Rekapitulasi Keuntungan Usaha PT KAI (Persero) dan PT Pelindo (Persero)

\begin{tabular}{cccc}
\hline \multirow{2nyy}{n}{ No. } & Nama Perseroan & \multicolumn{2}{c}{ Keuntungan Usaha } \\
\cline { 3 - 4 } 1 & PT KAI (Persero) & Rp.1,82 triliyun & Rp.2,64 triliyun \\
\hline 2 & PT Pelindo I (Persero) & Rp.1,063 triliyun & Rp.1,17 triliyun \\
\hline 3 & PT Pelindo II (Persero) & Rp.1,5 triliyun & Rp.2,2 triliyun \\
\hline 4 & PT Pelindo III (Persero) & Rp.454 milyar & Rp.413 Milyar \\
\hline 5 & PT Pelindo IV (Persero) & Rp.330 milyar & Rp.428 milyar \\
\hline
\end{tabular}

Sumber: Pengolahan data laporan keuangan masing-masing BUMN, Desember $2018 .{ }^{37}$

Berdasarkan informasi yang terdapat dalam Tabel di atas terlihat hanya PT Pelindo III (Persero) saja yang mengalami penurunan laba usaha perseroan. Sedangkan keempat BUMN lainnya mengalami peningkatan laba usaha di tahun 2017. Peningkatan laba usaha perseroan merupakan salah satu indikator untuk melihat kinerja BUMN.

Profit target laba usaha BUMN yang dari tahun ke tahun memperlihatkan peningkatan, menimbulkan asumsi dua aspek perspektif di dalamnya. Perspektif pertama, menunjukkan bahwa keempat BUMN tersebut akan mampu membiayai kegiatan usahanya secara mandiri dan terus menerus tanpa perlu penambahan penyertaan modal negara dalam rangka menutupi defisitnya keuangan BUMN. Perspektif kedua, dapat dimaknai bahwa telah terjadi pergeseran orientasi dari maksud dan tujuan pendirian BUMN yang semula untuk pelaksanaan kemanfaatan umum menjadi mengejar keuntungan sebagai prioritas utama. Kedua asumsi ini dimunculkan untuk menguji kebenaran akan korelasi antara peningkatan kinerja BUMN dengan maksud dan tujuan pendirian BUMN berdasarkan Undang-Undang BUMN. Perlu dipahami bahwa naik turunnya laba usaha perusahaan merupakan dinamika dalam menjalankan suatu korporasi. Gambaran dari tabel 1 di atas akan mudah dipahami apabila dibuat dalam bentuk grafik sebagai berikut:

\section{Bagan 1.}

\section{Grafik Laba Usaha PT KAI (Persero) dan PT Pelindo (Persero)}

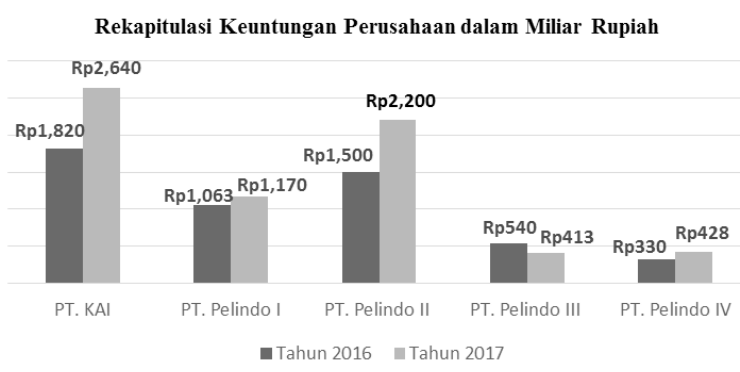

Sumber: Diolah oleh Penulis, 2019.

Berdasarkan gambaran laba usaha pada grafik di atas, terlihat bahwa PT KAI (Persero), PT

37 M. Nurhadi Pratomo, "Kinerja 2017: Laba Bersih KAI Tumbuh 67.64\%", https://m.bisnis.com/finansial/read/20180319/98/751393/kinerja2017-laba-bersih-kai-tumbuh-6764. Lihat juga Company Profil PT Kereta Api Indonesia (Persero) Tahun 2016, http://www.kai.id/company_ profile_2016.pdf, diakses 28 Mei 2018, hlm. 21.

Laporan Auditor Independen Kanaka Puradiredja \& Suhartono, Ref. : R-091/Pelindol-adf/SHT 01/II/2018, Laporan Keuangan Konsolidasian Pt Pelabuhan Indonesia I (Persero) dan Entitas Anak: untuk tahun yang berakhir pada tanggal 31 Desember 2017, Tanggal 12 Februari 2018. Laporan auditor independen Purwanto, Sungkoro \& Surja No.RPC-5826/PSS/2018, "Laporan keuangan konsolidasian PT Pelabuhan Indonesia II (Persero) dan entitas anaknya: Untuk Tahun yang berakhir Tanggal 31 Desember 2017”, tanggal 21 Februari 2018.

"Laporan Keuangan PT. Pelindo III (Persero) dan anak Perusahaan per 31 Maret 2018”, ditandatangani oleh President Direktur Bapak IG. N. Askhara Danadiputra dan Direktur Keuangan Bapak U. Saefudin Noer, pada tanggal 18 April 2018 di Surabaya.

"Laporan Keuangan Pelindo4 Tahun 2015-Tengah 2018", http:/drive.google.com/open?id=1aArGnUxSYidxfiv9R_siBGM7CHkQ0t1w dalam www.inaport4.co.id/tentang-kami/101/laporan-keuangan-pelindo4-tahun-2015-tengah-2018, diakses 4 Juli 2018 
Pelindo I (Persero), dan PT Pelindo II (Persero) adalah perusahaan yang mampu memperoleh laba usaha hingga menembus angka triliun Rupiah, sedangkan kedua BUMN lainnya, yaitu PT Pelindo III (Persero) dan PT Pelindo IV (Persero) hanya mampu memperoleh laba usaha menembus angka miliar Rupiah.

Hal ini memperlihatkan bahwa strategi pembenahan kelembagaan untuk menjalankan kegiatan usaha masih menemui kendala. Faktor jangkauan usaha yang juga dipengaruhi oleh naik turunnya kurs, lokasi usaha yang sulit dijangkau berdampak pada rendahnya harga komoditas, dan tingkat kepadatan arus transaksi yang berdampak pada perbedaan permintaan dan penawaran dari stakeholder BUMN tersebut, dijadikan alasan kuat untuk menyatakan bahwa hasil laba usaha menjadi tidak merata perolehannya. ${ }^{38}$ Belum lagi persoalan inkonsistensi kebijakan pemerintah yang diberlakukan pada BUMN, Abimayu (2011) menyatakan bahwa Konsistensi antara kinerja keuangan, permodalan, kebijakan teknis dan pengelolaan termasuk pemilihan direksi dan komisaris sangatlah esensial dalam menentukan target kinerja yang telah ditetapkan oleh BUMN, kenyataannya semuahal tersebutmasih dilaksanakan dengan sentuhan nuansa politisasi, sehingga kinerja BUMN menjadi belum maksimal, khususnya dalam memperoleh laba usaha. ${ }^{39}$

Target utama peningkatan kinerja BUMN ini adalah upaya untuk mendorong naiknya laba usaha perseroan. Sinergi antara Kementerian BUMN dan Kementerian Perhubungan dalam melakukan pembinaan PT KAI (Persero) dan PT Pelindo (Persero) menjadi kunci keberhasilan peningkatan kinerja BUMN bersangkutan.

\section{Keunggulan Kebijakan Demonopolisasi PT KAI (Persero) dan PT Pelindo (Persero) bagi Penguatan Ekonomi Indonesia.}

Sejalan dengan upaya pemerintah untuk meningkatkan kinerja BUMN, demonopolisasi BUMN merupakan langkah perbaikan untuk merangsang BUMN dalam hal menemukan strategi percepatan, khususnya dalam penguatan kelembagaannya agar mampu bersaing dalam perdagangan bebas. Konsep demonopolisasi yang menginginkan perseroan membangun budaya korporat (korporatisasi BUMN), sehingga mampu berkompetisi dengan perusahaan swasta dalam memenuhi kebutuhan masyarakat, adalah upaya untuk merealisasikan tujuan dari didirikannya BUMN. BUMN yang menjalankan usaha secara berkompetisi tentunya akan berupaya meningkatkan kualitas produksi dan pelayanan. Harapannya adalah konsumen lebih banyak memilih produk yang ditawarkannya sehingga keuntungan maksimal dapat diperoleh BUMN tersebut. Keuntungan memang menjadi kunci utama dalam menjalankan kegiatan usaha, tetapi khusus bagi BUMN, keuntungan bukanlah hal utama yang menjadi maksud dan tujuan didirikannya BUMN, ada tujuan mulia sebagai agent of development yang melandasi pendirian BUMN. Apabila kita merujuk kembali tujuan dari didirikannya BUMN yang terdapat dalam pasal 2 Undang-Undang BUMN, yaitu:

a. Memberikan sumbangan bagi perkembangan perekonomian nasional pada umumnya dan penerimaan negara pada khususnya;

b. Mengejar keuntungan;

c. Menyelenggarakan kemanfaatan umum berupa penyediaan barang dan/ atau jasa yang bermutu tinggi dan memadai bagi pemenuhan hajat hidup orang banyak;

d. Menjadi perintis kegiatan-kegiatan usaha yang belum dapat dilaksanakan oleh swasta atau koperasi;

e. Turut aktif memberikan bimbingan dan bantuan kepada pengusaha golongan ekonomi lemah, koperasi dan masyarakat.

\footnotetext{
38 Sunarsip, "Menyoroti Kinerja BUMN-Pelemahan Kinerja Perusahaan Plat Merah disebabkan oleh 3 Hal, https://tanjungintanport.wordpress. com/, lihat juga Immanuel Giras Pasopati, "Kinerja Lamban BUMN Jokowi”, https://m.cnnindonesia.com/ekonomi/, diakses 12 Desember 2018.

39 Anggito Abimayu. "kinerja BUMN Tergantung Konsistensi Kebijakan” source: bumn.go.id/pelindo1/berita/7477. diakses 21 Okrober 2018.
} 
Berdasarkan dari kelima sub ayat di atas, huruf "a, c, d, dan e" dapat dikategorikan sebagai sub-ayat yang berorientasi sosial sesuai dengan tujuan dari Pasal 27 ayat (2) UUD NRI 1945 berkenaan dengan kesempatan kerja, Pasal 33 UUD NRI 1945 berkenaan dengan ekonomi kerakyatan/ demokrasi ekonomi, dan Pasal 34 UUD NRI 1945 berkenaan dengan menghilangkan kemiskinan. Sedangkan tujuan BUMN yang terdapat dalam sub "b" dapat dikategorikan sebagai sub ayat yang berorientasi kapitalisme.

Demonopolisasi BUMN yang dilakukan pemerintah memang didasarkan pada peraturan perundang-undangan, orientasi meningkatkan kinerja BUMN dengan menghadirkan keterlibatan swasta dalam bentuk menjadi kompetitor BUMN atau melalui pengelolaan BUMN dengan mekanisme korporatisasi penjualan maksimal saham 49\%, dengan harapan BUMN dapat memperoleh keuntungan dan mampu mandiri, sehingga tidak terus menerus membebani keuangan pemerintah untuk menambah penyertaan modal atau subsidi. Kelihatannya bahwa tindakan demonopolisasi BUMN terpengaruh pada pemikiran kapitalis dan neo-liberal, bahkan terlihat tidak mencerminkan ekonomi kerakyatan atau demokrasi ekonomi. Atas dasar hal inilah akan dibahas lebih lanjut mengenai kesesuaian konsep demonopolisasi BUMN dengan maksud dan tujuan BUMN yang terdapat dalam Pasal 2 Undang-Undang BUMN, yaitu: ${ }^{40}$

1) Pada prinsipnya suatu badan usaha didirikan untuk mencari keuntungan dankeuntungan yang diperoleh tersebut pada prinsipnya akan diperuntukkan bagi pemilik modal. Konsep demonopolisasi BUMN pada dasarnya menghendaki BUMN memiliki kompetitor dalam menjalankan usaha atau menerapkan korporatisasi dengan memberikan kesempatan swasta untuk berperan dalam membangun kinerja
BUMN melalui kepemilikan saham BUMN maksimal 49\%, dengan kata lain demonopolisasi BUMN tidak menghilangkan kepemilikan BUMN oleh pemerintah. Artinya keuntungan yang diperoleh BUMN akan kembali kepada pemerintah. PT KAI (Persero) dan PT Pelindo (Persero) adalah BUMN yang kepemilikan saham perusahaannya $100 \%$ dimiliki oleh pemerintah, artinya keuntungan usaha yang diperoleh akan kembali kepada pemerintah. Keuntungan BUMN tersebut akan dialokasikan untuk pembayaran pajak, pembagian dividen/dividen per shares kepada pemilik modal yang tidak lain adalah pemerintah, dan untuk pengembangan usaha yang artinya menambah lapangan pekerjaan secara berkala.

2) Kecenderungan yang terjadi di saat suatu lembaga atau badan usaha dibebani beberapa tujuan untuk dicapai, masalah utamanya adalah penentuan prioritas tujuan mana yang akan didahulukan atau diberikan perhatian khusus. Sama halnya dengan BUMN memang memiliki lima tujuan pendirian, BUMN yang didemonopolisasi juga harus menjalankan kelima tujuan tersebut. Hal yang menjadi poin penting adalah bahwa BUMN yang didemonopolisasi adalah BUMN yang semula menjalankan kegiatan usaha untuk memberikan pelayanan atau kemanfaatan publik. PT KAI (Persero) dan PT Pelindo (Persero) adalah jenis BUMN yang memberikan pelayanan publik dalam hal perkeretaapian dan operator pelabuhan. PT KAI (Persero) dan PT Pelindo (Persero) pada saat menjalankan kegiatan usaha tentunya berpijak pada tujuan yang dinyatakan dalam Pasal 2 Undang-Undang BUMN. Hal yang menjadi lumrah ketika PT KAI (Persero) dan PT Pelindo (Persero) lebih mengorientasikan salah

\footnotetext{
40 Resume Focus Group Discussion yang dilakukan dengan Senior Vice President (SVP) Pemasaran, SVP Hukum, Deputy Vice President (DVP) Strategi Pemasaran, DVP Pentarifan, DVP hubungan Pelanggan Petikemas, DVP Hubungan Pelanggan Non Petikemas, DVP Dukungan Hukum PT Pelindo II (Persero), Kamis, 21 Maret 2019, Pukul 09.00 s/d 12.00 WIB, di Ruang Rapat Armada I dan wawancara dengan staff legal (EVP Legal) PT KAI (Persero) Kantor Pusat Bandung, Selasa, 23 Oktober 2018.
} 
satu tujuan dari lima tujuan dasar yang harus dipenuhi berdasarkan Pasal 2 Undang-Undang BUMN, tetapi yang harus dipertegas bahwa prioritas terhadap salah satu tujuan, tidak akan menghilangkan peran BUMN tersebut untuk memenuhi tujuan lainnya. Hal inilah yang membedakan badan usaha milik negara dengan badan usaha milik swasta yang dapat saja meninggalkan salah satu dari kelima tujuan tersebut. Keberadaan BUMN yang menjalankan kegiatan usaha berkaitan dengan kepentingan publik harus mampu dipertahankan, hal ini demi memberikan pelindungan kepada rakyat banyak atas dasar kemampuan daya beli masyarakat terhadap kesediaan produk yang ditawarkan.

3) Kelima tujuan pendirian BUMN tersebut memiliki kedudukan yang sama pentingnya, tetapi secara implisit penerapan di lapangan akan muncul kecenderungan untuk lebih memprioritaskan salah satu, terutama pada saat segala sumber daya yang diperlukan terbatas adanya umumnya yang akan didahulukan adalah persoalan tujuan mencari keuntungan. Kondisi ini juga didukung dengan poin indikator keberhasilan BUMN adalah perolehan capaian keuntungan usaha. Sebagai bukti adalah dalam setiap laporan tahunan (annual report) BUMN termasuk PT KAI (Persero) dan PT Pelindo (Persero) hal yang dibicarakan adalah laporan keuangan BUMN dalam posisi laba atau merugi, begitu juga dalam laporan catatan akhir Kementerian BUMN, yang dipublikasi adalah jumlah BUMN yang memperoleh keuntungan usaha dan jumlah BUMN yang mengalami kerugian usaha. Hampir tidak pernah didengar penjelasan mengenai kegiatan-kegiatan BUMN yang terkait dengan keempat tujuan lain dari pendirian BUMN selain mencari keuntungan seperti yang dijabarkan oleh Pasal 2 huruf a, c, d, dan e UndangUndang Nomor 19 Tahun 2003 tentang BUMN. Kenyataan ini memosisikan BUMN untuk aktif terus berusaha mencari strategi untuk meningkatkan laba usaha dari tahun ke tahun. Arah yang diharapkan ketika BUMN PT KAI (Persero) dan PT Pelindo (Persero) memiliki kompetitor, maka mutu layanan dan keterjangkauan harga akan terus ditingkatkan, karena mutu layanan dan harga bersaing yang lebih baik dari kompetitor akan menarik konsumen, jumlah konsumen yang meningkat tentunya akan berbanding lurus dengan peningkatan keuntungan perseroan.

4) Demonopolisasi BUMN Persero yang bergerak di bidang usaha publik seperti halnya PT KAI (Persero) dan PT Pelindo (Persero) mengharapkan kehadiran kompetitor baru dari swasta, bukan konsep kepemilikan BUMN yang dialihkan menjadi milik swasta seperti halnya privatisasi. Pilihan dengan menghadirkan pesaing bisnis bagi BUMN justru malah menguntungkan perekonomian bangsa Indonesia. Pendirian perusahaan swasta yang menjadi kompetitor BUMN akan berkontribusi bagi perekonomian negara, baik secara langsung maupun tidak langsung. Pesaing BUMN akan memberikan kontribusi langsung kepada negara melalui pembayaran pajak, penyerapan tenaga kerja, belanja modal (capital expenditure) perusahaan, belanja operasional (operational expenditure) perusahaan, pilihan bagi konsumen dalam penyediaan barang dan jasa, community development dan program pembinaan usaha kecil melalui kewajiban pelaksanaan Corporate Social Responsibility (CSR). Sedangkan kontribusi secara tidak langsung berupa kegiatan yang menggerakkan roda perekonomian nasional (multiplier effect) yang di dalamnya memungkinkan merambah pada perekonomian daerah.

Penegasan lebih lanjut mengenai keuntungan dari orientasi mengejar keuntungan yang dilakukan oleh BUMN dinyatakan oleh Revrisond Baswir, yang memaknai keuntungan BUMN dapat ditinjau 
dari sudut pandang keuntungan bagi BUMN sendiri dan dari sudut pandang keuntungan bagi negara. Bagi BUMN sendiri, keuntungan usaha yang diperoleh akan memperkuat likuiditas perusahaan, meningkatkan kemampuan perseroan dalam membayar utang-utangnya, dan yang terpenting BUMN tersebut dapat mengurangi ketergantungan terhadap pembuatan utang baru. Sedangkan keuntungan bagi pemerintah, BUMN yang memperoleh keuntungan dalam menjalankan usahanya, maka BUMN tersebut akan mampu memenuhi keseluruhan maksud dan tujuan pendirian BUMN berdasarkan Pasal 2 UndangUndang BUMN. ${ }^{41}$

Menghadirkan kompetitor bagi PT KAI (Persero) dan PT Pelindo (Persero) atau dengan memberikan peran swasta yang ikut berpartisipasi dalammembangun BUMN tersebut, akanberdampak pada semangat memperbaiki kinerja BUMN agar dapat mampu bertahan dan menjalankan kegiatan usahanya secara berkelanjutan. Posisi BUMN yang tetap menjadi milik pemerintah tentunya akan tetap berjalan sesuai amanah yang terdapat dalam Pasal 2 Undang-Undang BUMN. Artinya, konsep demonopolisasi PT KAI (Persero) dan PT Pelindo (Persero) sejalan dengan tujuan pendirian BUMN yang tidak hanya mengejar keuntungan tetapi juga sebagai agent of development yang berorientasi terhadap pemenuhan kemanfaatan bagi masyarakat Indonesia. Hal yang utama juga dalam pelaksanaan kinerja BUMN Persero yang kepemilikan usahanya adalah pemerintah, maka penerapan prinsip-prinsip ekonomi kerakyatan atau demokrasi ekonomi yang terdapat dalam Pasal 33 UUD NRI 1945 dapat diterapkan dalam kinerja BUMN Persero tersebut. Artinya, jaminan atas perlindungan terhadap aset-aset kekayaan negara yang merupakan cabang-cabang produksi penting dan jaminan atas perlindungan bagi kepentingan hajat hidup orang banyak dapat juga dilaksanakan oleh BUMN Persero tersebut.

\section{Kesimpulan}

Demonopolisasi terhadap PT KAI (Persero) dan PT Pelindo (Persero) merupakan kebijakan pemerintah yang didorong oleh tuntutan globalisasi dengan membuka pasar bebas tanpa batas-batas sebagai hambatan. Di sisi lain kebijakan ini juga merupakan salah satu bentuk memantapkan posisi BUMN sebagai korporasi dan agent of development agar keluar dari zona nyaman khususnya yang selama ini menjalankan usaha secara monopoli. Menciptakan kompetitor bagi BUMN, membuat BUMN berupaya untuk menguatkan kelembagaannya melalui korporatisasi, dengan mengimplementasikan prinsip principal agent dan tata kelola perusahaan yang baik. Hal yang membedakan cara kerja BUMN Indonesia dengan milik negara lain adalah penerapan konsep ekonomi demokrasi yang mengedepankan asas kekeluargaan yang berorientasi pada prinsip efisiensi berkeadilan bagi seluruh masyarakat Indonesia.

Hal utama dari pelaksanaan kebijakan demonopolisasi dan penguatan kelembagaan bagi PT KAI (Persero) dan PT Pelindo (Persero) adalah kemampuan untuk membuat jejaring antara pemerintah sebagai regulator, dunia usaha sebagai pelaku pasar, dan masyarakat sebagai pengguna produk/jasa. Pembangunan nasional dengan menggunakan konsep demokrasi ekonomi memadukan prinsip kebersamaan, efisiensi berkeadilan, berkelanjutan, berwawasan lingkungan, kemandirian, serta menjaga keseimbangan, kemajuan, dan kesatuan ekonomi nasional yang arahnya menjamin keadilan dan sebesar-besar kemakmuran rakyat.

Harapan yang ingin dicapai bagi kinerja PT KAI (Persero) dan PT Pelindo (Persero) adanya peningkatan kemampuan dalam menyinergikan capaian profit motif dan pemberi kemanfaatan bagi masyarakat. Kemanfaatan bagi negara apabila tetap mempertahankan BUMN yang memberikan pelayanan publik seperti KAI dan Pelindo adalah

41 Pandangan Revrisond Baswir sebagai saksi ahli dalam Putusan Mahkamah Konstitusi No.14/PUU-XVI/2008 tentang Pengujian UndangUndang Nomor 19 Tahun 2003 tentang Badan Usaha Milik Negara terhadap Undang-Undang Dasar Negara Republik Indonesia Tahun 1945. 
keuntungan akan menjadi milik negara, mulai dari pembagian dividen, pemasukan pajak, perlindungan terhadap aset negara, penyerapan tenaga kerja lokal, pemenuhan akan pelayanan umum, hingga programprogram kemitraan melalui mekanisme CSR.

\section{DAFTAR PUSTAKA}

\section{A. Buku}

Anggoro, Teddy, 2016, Monopoli Alamiah Badan Usaha Milik Negara, Herya Media, Depok.

Dupuit, Jules, 2016, Monopoli Alamiah Badan Usaha Milik Negara, Herya Media, Depok.

Gie, Kwik Kian, 1998, Praktik Bisnis dan Orientasi Ekonomi Indonesia, PT Gramedia Pustaka Utama \& IBBI, Jakarta.

Hartini, Rahayu, 2017, BUMN Persero: Konsep Keuangan Negara dan Hukum Kepailitan di Indonesia, Setara Press, Malang.

Hartono, Sunaryati, 1994, Penelitian Hukum di Indonesia Pada Akhir Abad ke 20, Alumni, Bandung

Hatta, Mohammad, 1970, "Sesudah 25 Tahun", dalam Revrisond Baswir, 2010, Manifesto Ekonomi Kerakyatan, Pustaka Pelajar, Yogyakarta,

Kreinin, Mordechai E., 1990, International Economics; A Policy Approach, Harcout Brace Javanovich Inc., New York.

Mubyarto, et.al., 1989, Pelaku dan Politik Ekonomi Indonesia. UGM Press, Yogyakarta.

Muhadjir, Noeng, 1998, Metodologi Penelitian Kualitatif, Rake Sarasin, Yogyakarta.

Prabowo, Dibyo, "Penjabaran Pasal 33 ayat (2) UUD 1945 dalam Kebijaksanaan". dalam Mubyarto et.al., 1989, Pelaku dan Politik Ekonomi Indonesia, UGM Press, Yogyakarta.

Salim, Emil, "Pokok-pokok Pikiran: membangun Koperasi dan Sistem Ekonomi Pancasila", dalam Sri Edi Swasono (ed.), 2010, Membangun Sistem Ekonomi NasionalSistem Ekonomi dan Demokrasi Ekonomi, UI Press, JakartaAeiu

Sartono, Agus R., 1999, Manajemen Keuangan Teori dan Aplikasi, BPFE UGM, Yoyakarta.
Sidharta, Bernard Arief , 2001, Filsafat Ilmu Hukum, Laboratorium Hukum Fakultas Hukum Universitas Khatolik Parahyangan, Bandung.

Stiglizt, Joseph E., 2007, Making Globalization Work: Menyiasati Globalisasi Menuju Dunia yang Lebih Adil, Diterjemahkan Edrijani Azwaldi, Mizan, Bandung.

Sunggono, Bambang, 2007, Metodologi Penelitian Hukum, PT Raja Grafindo Persada, Jakarta.

Soejono, et.al., 2003, Metode Penelitian Hukum, PT Rineka Cipta, Jakarta.

Soekanto, Soerjono, et.al., 2006, Penelitian Hukum Normatif, Rajawali, Jakarta.

\section{B. Artikel Jurnal}

Berov, Liuben, "Demonopolization and International Competition in Bulgaria 1990-1991", Russian and Eastern European Finance and Trade Journal, Vol. 29, No.1 Tahun 1993.

Diana, Andini Tri, "Analisis Tingkat Kesehatan Perusahaan dalam Menilai Kinerja Keuangan Perusahaan BUMN", Jurnal Integra, Vol. 6, No. 1, Januari 2016.

Martin, Jay G., "An Overview of The Privatization of The Latin American Oil and Gas Sector", Natural Resources \& Environment Journal, Vol.14, No.2, Tahun 1999.

Petersen, Niels "Antitrust Law and The Promotion of Democracy and Economic Growth", Journal of Competition Law \& Economic, Vol. 9, No. 3, Tahun 2013.

Rodriques, Artur, et.al., "Investment Decisions in Granted Monopolies Under The Threat of a Random Demonopolization." Economic Jornal Faculty of Economic University of Parto, 2011 
C. Makalah/Pidato

Baginska, Ewa, "Privatization Proses in Poland: Legal Aspect of The Privatization Process in Poland", Makalah, Nicolaus Copernicus University, Poland, 1995.

\section{Artikel Majalah}

Hatta, Mohammad, "Pelaksanaan Undang-Undang Dasar 1945 Pasal 33", Majalah Gema Angkatan 45, 1977.

\section{E. Internet}

Anggito Abimayu. "Kinerja BUMN Tergantung Konsistensi Kebijakan", bumn.go.id/ pelindol/berita/7477, diakses 21 Okrober 2018.

Badan Perencanaan dan Pembangunan Nasional, 2015, "Biaya pelabuhan", https://www. bappenas.go.id/files/, diakses 7 Februari 2017.

Kamus Besar Bahasa Indonesia online, "Kamus Besar Bahasa Indonesia Online", http://kbbi. web.id/demonopolisasi.html, diakses 25 Mei 2016.

Sunarsip, "Menyoroti Kinerja BUMN-Pelemahan Kinerja Perusahaan Plat Merah disebabkan oleh 3 Hal, https://tanjungintanport. wordpress.com/, lihat juga Immanuel Giras Pasopati, "Kinerja Lamban BUMN Jokowi", https://m.cnnindonesia.com/ekonomi/, diakses 12 Desember 2018.

\section{F. Keputusan}

Keputusan Menteri Keuangan RI Nomor 740/ KMK.00/1989 tanggal 28 Juni 1989 tentang
Peningkatan Efisiensi dan Produktifitas BUMN.

\section{G. Putusan Pengadilan}

Putusan Mahkamah Konstitusi Nomor 002/ PUU-I/2003 tentang Pengujian UndangUndang Nomor 22 Tahun 2001 tentang Minyak dan Gas Bumi.

Putusan Mahkamah Konstitusi Nomor 36/ PUU-X/2012 tentang Pengujian Undangundang Nomor 22 Tahun 2001 tentang Minyak dan Gas Bumi.

\section{H. Dokumen Lain}

Laporan Auditor Independen Kanaka Puradiredja \& Suhartono, Ref. : R-091/Pelindol-adf / SHT 01/II/2018, Laporan Keuangan Konsolidasian PT Pelabuhan Indonesia I (Persero) dan Entitas Anak: untuk tahun yang berakhir pada tanggal 31 Desember 2017, Tanggal 12 Februari 2018.

Laporan auditor independen Purwanto, Sungkoro \& Surja No.RPC-5826/PSS/2018, "Laporan keuangan konsolidasian PT Pelabuhan Indonesia II (Persero) dan entitas anaknya: Untuk Tahun yang berakhir Tanggal 31 Desember 2017", tanggal 21 Februari 2018.

Laporan Keuangan PT Pelindo III (Persero) dan anak Perusahaan per 31 Maret 2018", ditandatangani oleh President Direktur Bapak IG. N. Askhara Danadiputra dan Direktur Keuangan Bapak U. Saefudin Noer, pada tanggal 18 April 2018 di Surabaya. 